\title{
CONFIRMED CASES OF TUBERCULOSIS IN BRAZIL, IN THE NORTH REGION, IN THE STATE OF AMAPÁ AND IN THE MUNICIPALITY OF MACAPÁ, BETWEEN 2013 AND 2017
}

\section{ORIGINAL ARTICLE}

JESUS, Michele da Cruz de ${ }^{1}$, SILVA, Lucas Facco ${ }^{2}$, FECURY, Amanda Alves ${ }^{3}$, OLIVEIRA, Euzébio de ${ }^{4}$, DENDASCK, Carla Viana ${ }^{5}$, DIAS, Cláudio Alberto Gellis de Mattos $^{6}$

JESUS, Michele da Cruz de. Et al. Confirmed cases of tuberculosis in Brazil, in the North Region, in the State of Amapá and in the Municipality of Macapá, between 2013 and 2017. Revista Científica Multidisciplinar Núcleo do Conhecimento. Year 05, Ed. 05, Vol. 01, pp. 144-154. August 2020. ISSN:24480959, Access link in: https://www.nucleodoconhecimento.com.br/health/tuberculosisin-brazil, DOI: 10.32749/nucleodoconhecimento.com.br/health/tuberculosis-in-brazil

\section{ABSTRACT}

Tuberculosis (TB) is an infectious disease caused by pathogenic bacteria. The bacillus is transmitted mainly through the coughing mechanism, in addition to sneezing and speech, which are responsible for releasing droplets of saliva. In Brazil, 69,569 new cases of tuberculosis were confirmed in 2017. In the Brazilian state of Amapá, still in 2017, there were 237 new cases of tuberculosis reported. The objective of this work is to compare the percentage of confirmed cases of

\footnotetext{
${ }^{1}$ Physical Education Course Student, Federal University of Amapá (UNIFAP).

${ }^{2}$ Medical School Student, Federal University of Amapá (UNIFAP).

${ }^{3}$ Biomedical, PhD in Topical Diseases, Professor and researcher of the Medicine Course at Campus Macapá, Federal University of Amapá (UNIFAP).

${ }^{4}$ Biologist, PhD in Topical Diseases, Professor and researcher of the Physical Education Course at, Federal University of Pará (UFPA).

${ }^{5}$ Theologian, PhD in Psychoanalysis, researcher at the Center for Research and Advanced Studies - CEPA.

${ }^{6}$ Biologist, PhD in Theory and Research of Behavior, Professor and researcher of the Chemistry Degree Course at the Basic, Technical and Technological Institute of Amapá (IFAP).
}

RC: 49737

Available in: https://www.nucleodoconhecimento.com.br/health/tuberculosis-in-brazil 
tuberculosis in Brazil, in the North region, in the state of Amapá and in the municipality of Macapá, between the years 2013 and 2017. Data were collected on the DATASUS website. Co-infections as well as alcoholism, drug use, urban agglomerations and the individual's nutritional status can also represent factors that increase tuberculosis cases. Social vulnerability and little primary health care also favor an increase in these numbers. Having a Tropical Diseases Reference Center (CRDT), which also includes the Testing and Counseling Center (CTA) and Therapeutic Home Assistance (ADT) helps in detecting cases, streamlining and controlling the treatment of patients. Men in the working age group are more affected due to their necessary social interaction for work.

Keywords: Tuberculosis, epidemiology, North region, Amapá.

\section{INTRODUCTION}

Tuberculosis (TB) is an infectious disease caused by the pathogenic bacterium Mycobacterium tuberculosis, also known as Koch's bacillus (KB)(MACEDO et al., 2017).

Once infected, about 5 to $10 \%$ of individuals have active tuberculosis and, depending on the affected organ, can manifest a series of symptoms, coughing being the most common of them, evolving from dry to mucous and sometimes associated blood, characterizing hemoptysis (coughing blood). The condition can progress to chest pain and, less commonly, dyspnea (difficulty breathing), both caused by injury and effusion of the pleural cavity. Fever and weight loss can also be manifestations of the disease (KOZAKEVICH e SILVA, 2015).

The bacillus is transmitted mainly through the coughing mechanism, in addition to sneezing and speech, which are responsible for releasing droplets of saliva (called Flügge droplets) that, depending on their weight, can remain in air suspension and allow the infection when reaching bronchioles and pulmonary alveoli. Taking into account the degree of contact and proximity, it is estimated that an exposure of about

$\mathrm{RC}: 49737$

Available in: https://www.nucleodoconhecimento.com.br/health/tuberculosis-in-brazil 
100 hours or more is necessary for interpersonal infection (KOZAKEVICH e SILVA, 2015).

Tuberculosis (TB) is curable through effective treatment, which is performed with the use of various anti-TB drugs (SILVA et al., 2018). According to the PNCT (National Tuberculosis Control Program), of the Ministry of Health - Brazil, there are four drugs used in the basic scheme for the treatment of tuberculosis, in combined form, in adults and adolescents: Rifampicin $150 \mathrm{mg}$, Isoniazid 75mg, Pyrazinamide 400mg and Ethambutol $275 \mathrm{mg}$. In the case of the disease in children, Ethambutol $275 \mathrm{mg}$ is removed from the regimen, using only the first three (BRASIL, 2019).

In order to seek prevention against tuberculosis, BCG vaccine has been used in many countries since the last century, since the 1920s, in children aged 0 to 4 years. It prevents serious forms of the disease, such as miliary tuberculosis (which spreads in the body and can cause skin lesions) and meningeal (which can reach the tissues that surround the brain, called meninges). In Brazil, the vaccination goal advocated by the National Immunization Program (PNI) is $90 \%$ of children under the age of 1 year, which has been reached and extrapolated (BRASIL, 2018). Although it is effective in children, the BCG vaccine does not show the same preventive efficacy in adults, indicating that an efficient vaccine is needed for the broad age spectrum of individuals (CARVALHO et al., 2018).

It is estimated that about $25 \%$ of the world population is infected with Mycobacterium tuberculosis. In 2017, as a result of tuberculosis, approximately 6.4 million people became ill, of whom about a quarter died (WHO, 2019).

In Brazil, 69,569 new cases of tuberculosis were confirmed in 2017, and in 2016, there were 4,426 deaths due to this disease. (BRASIL, 2018).

In the northern region of the country, in 2017, 7653 new cases of tuberculosis were registered, with an incidence of 42.7 per 100 thousand inhabitants and a mortality coefficient of 2.4 per 100 thousand inhabitants. (BRASIL, 2018).

RC: 49737

Available in: https://www.nucleodoconhecimento.com.br/health/tuberculosis-in-brazil 
In the Brazilian state of Amapá, still in 2017, there were 237 new cases of tuberculosis reported, with an incidence rate of 29.7 per 100,000 inhabitants, while the mortality rate was 1.4 per 100,000 inhabitants. (BRASIL, 2018).

\section{AIM}

Compare the percentage of confirmed tuberculosis cases in Brazil, in the North, in the state of Amapá and in the municipality of Macapá, between the years 2013 and 2017.

\section{METHOD}

Data were collected on the DATASUS website[7]. From the following steps: A) Through the Chrome internet browser, the link[8] was accessed, in the function bar of the site, the mouse was moved over the option "Access to information "keeping it on top, in the tab that opened, the mouse was dragged to the option" Health Information (TABNET) "and again another tab was opened in which was clicked on" Morbidity epidemics ". On the next page, the option "Cases of Tuberculosis - Since 2001 (SINAN)" was selected. The only option was chosen on the next page "Tuberculosis since 2001". On the same page, within the "Geographic scope" selection box, the option "Brazil by Region, State and Municipality" was selected. A) On the page that followed, in the box where you requested "Line", selected the "Year of Notification" option; in the box that requested "Column", the option "Region of Notification" was selected; and in the "Available periods" box, the years 2013 to 2017 were selected. B) On the page that followed, in the box where requested "Line", selected the option "Year of Notification"; in the box that requested "Column", the option "Notification UF" was selected; and in the "Available periods" box, the years 2013 to 2017 were selected. C) On the page that followed, in the box where requested "Line", selected the option "Year of Notification"; in the box that requested "Column", the option "Notification Capital" was selected; and in the "Available periods" box, the years 2013 to 2017 were selected. D) On the page that followed, in the box where requested

RC: 49737

Available in: https://www.nucleodoconhecimento.com.br/health/tuberculosis-in-brazil 
"Line", selected the option "Year of Notification"; in the box that requested "Column", the option "Fx Age" was selected; and in the "Available periods" box, the years 2013 to 2017 were selected. E) On the following page, in the box where requested "Line", selected the "Notification Year" option; in the box that requested "Column", the option "Schooling" was selected; and in the "Available periods" box, the years 2013 to 2016 were selected. F) On the following page, in the box where requested "Line", selected the "Notification Year" option; in the box that requested "Column", the option "Gender" was selected; and in the "Available periods" box, the years 2013 to 2016 were selected. G) On the following page, in the box where requested "Line", selected the "Notification Year" option; in the box that requested "Column", the option "Residence Zone" was selected; and in the "Available periods" box, the years 2013 to 2017 were selected. Data were compiled within the Excel application, part of the Microsoft Corporation's Office package. The bibliography search was carried out on scientific articles, using computers from the computer lab of the Federal Institute of Education, Science and Technology of Amapá, Campus Macapá, located at: Rodovia BR 210 KM 3, s / n - Bairro Brasil Novo . CEP: 68.909-398, Macapá, Amapá, Brazil.

\section{RESULTS}

Figure 1 shows the percentage of confirmed cases of tuberculosis in Brazil between 2013 and 2017. Between the years 2013 and 2015 the percentage of cases decreased, increasing again in 2016 and 2017.

RC: 49737

Available in: https://www.nucleodoconhecimento.com.br/health/tuberculosis-in-brazil 
Figure 1 Shows the percentage of confirmed tuberculosis cases in Brazil between 2013 and 2017.

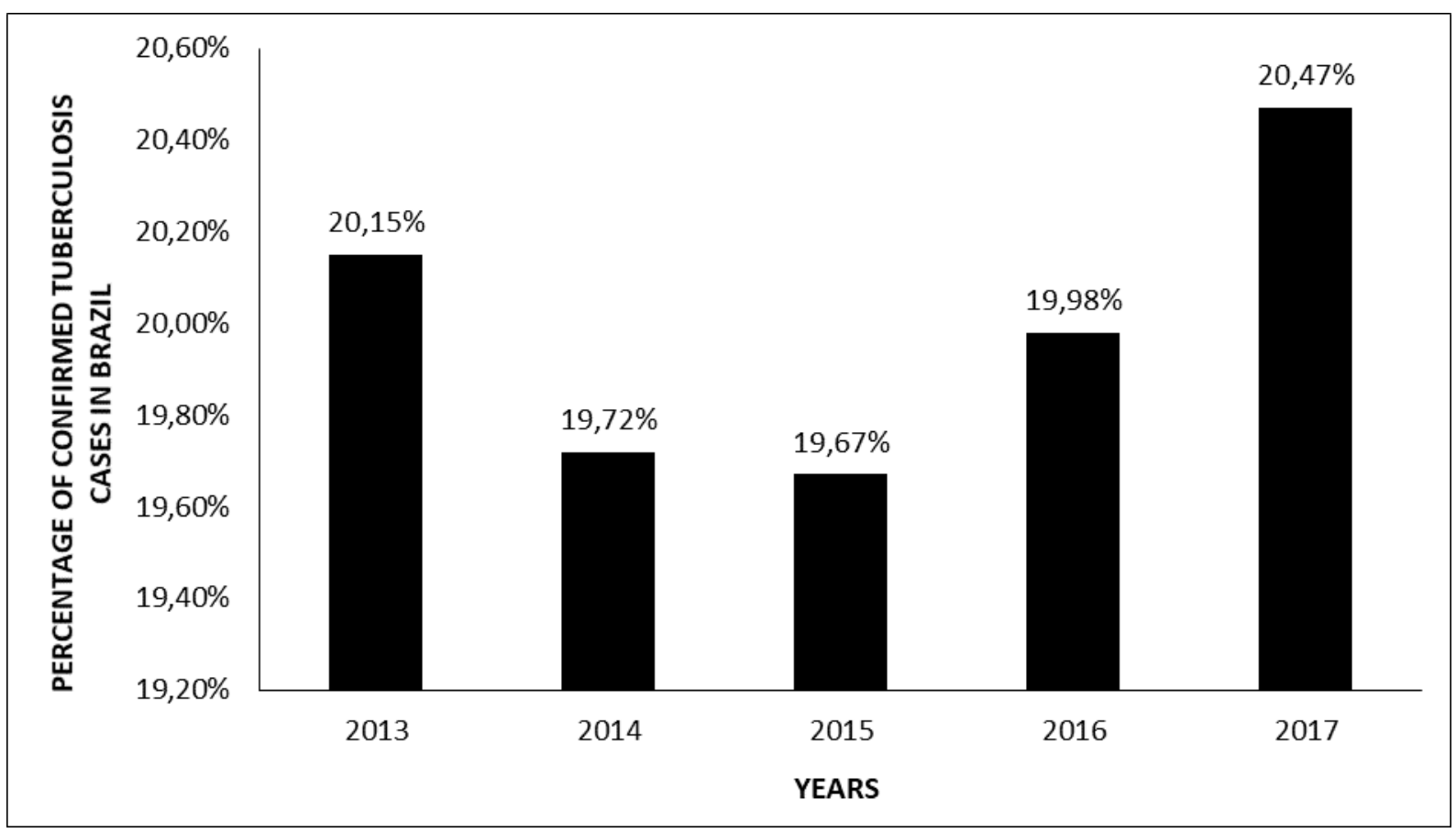

Figure 2 shows the percentage of confirmed cases of tuberculosis in the regions of Brazil between 2013 and 2017. The Southeast region has the highest percentage of confirmed cases, followed by the Northeast and South, while the lowest is in the Midwest and North..

RC: 49737

Available in: https://www.nucleodoconhecimento.com.br/health/tuberculosis-in-brazil 
Figure 2 Shows the percentage of confirmed tuberculosis cases in the regions of Brazil between 2013 and 2017.

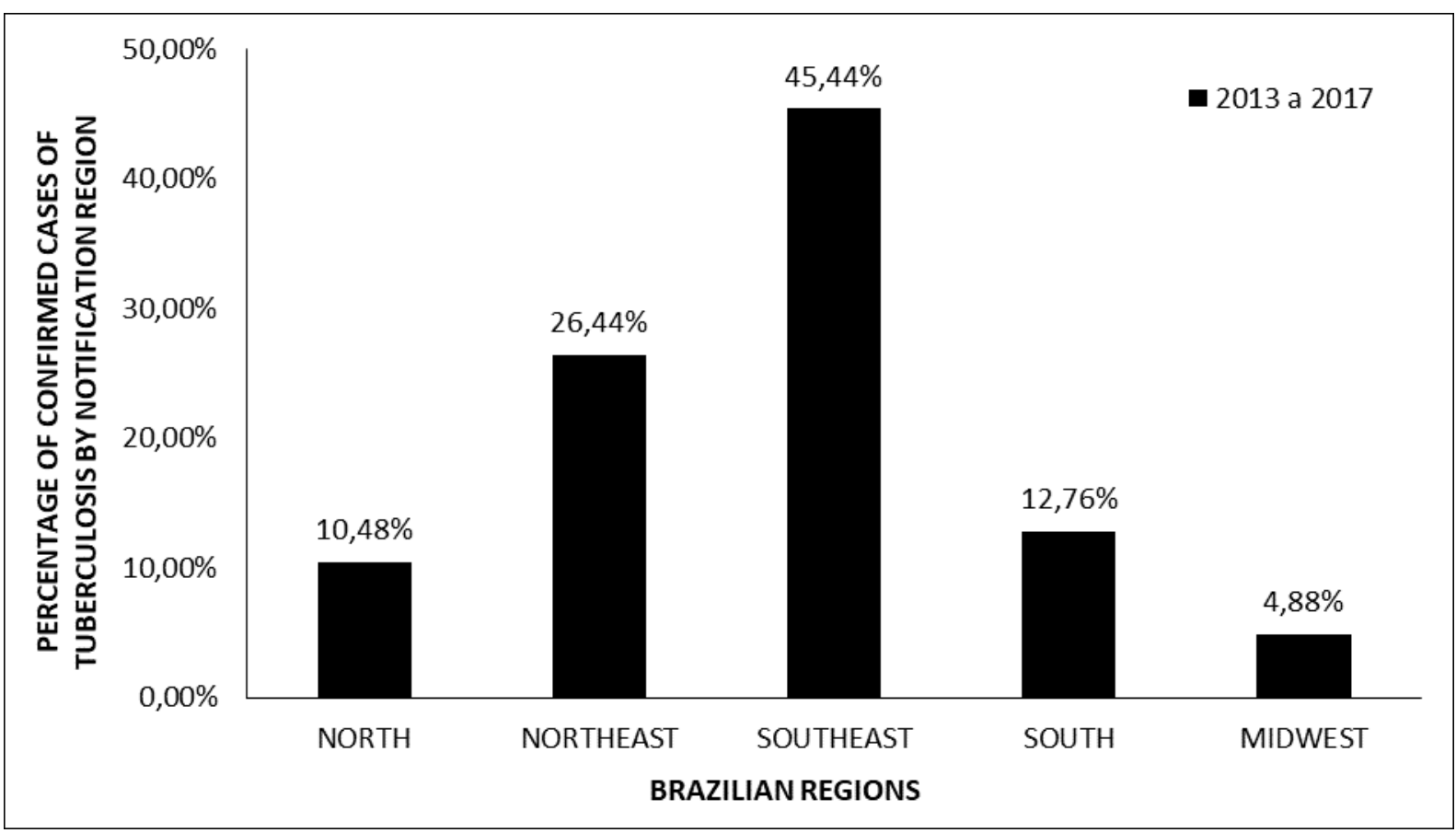

Figure 3 shows the percentage of confirmed tuberculosis cases between 2013 and 2017 in the northern region of Brazil. The highest percentages of confirmed tuberculosis cases are found in the states of Amazonas and Pará, while the lowest are in Rondônia, Acre, Amapá, Tocantins and Roraima.

RC: 49737

Available in: https://www.nucleodoconhecimento.com.br/health/tuberculosis-in-brazil 
Figure 3 Shows the percentage of confirmed tuberculosis cases between 2013 and 2017 in the northern region of Brazil.

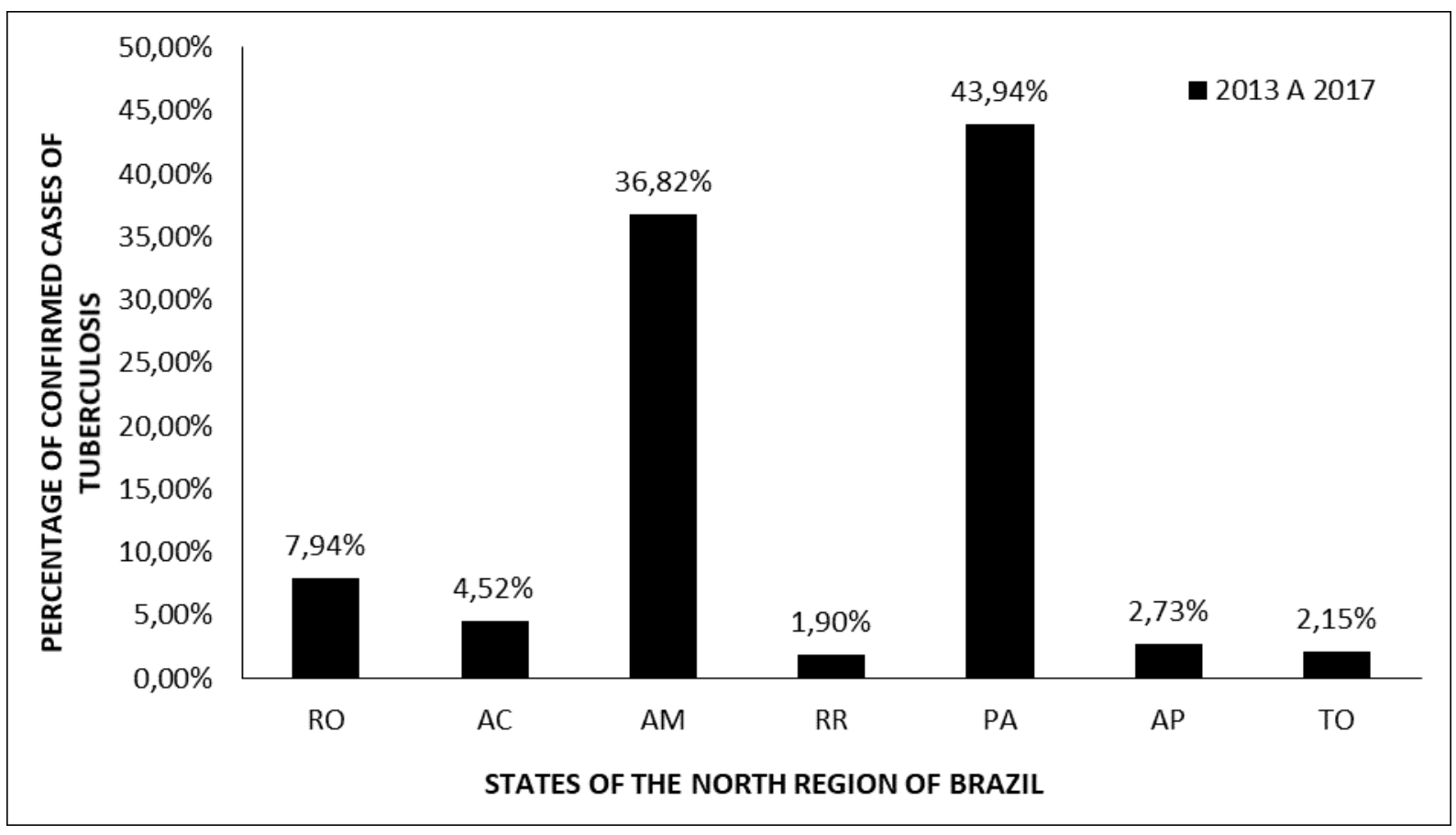

Figure 4 shows the percentage of confirmed cases of tuberculosis in the state of Amapá in Brazil between 2013 and 2017, between the years 2013 to 2015 there was little difference in the increase and decrease in confirmed cases, from 2015 to 2016 there was an increase in the percentage, and in 2017 it remained close to the percentage number next to 2016 .

RC: 49737

Available in: https://www.nucleodoconhecimento.com.br/health/tuberculosis-in-brazil 
Figure 4 Shows the percentage of confirmed tuberculosis cases in the state of Amapá in Brazil between 2013 and 2017.

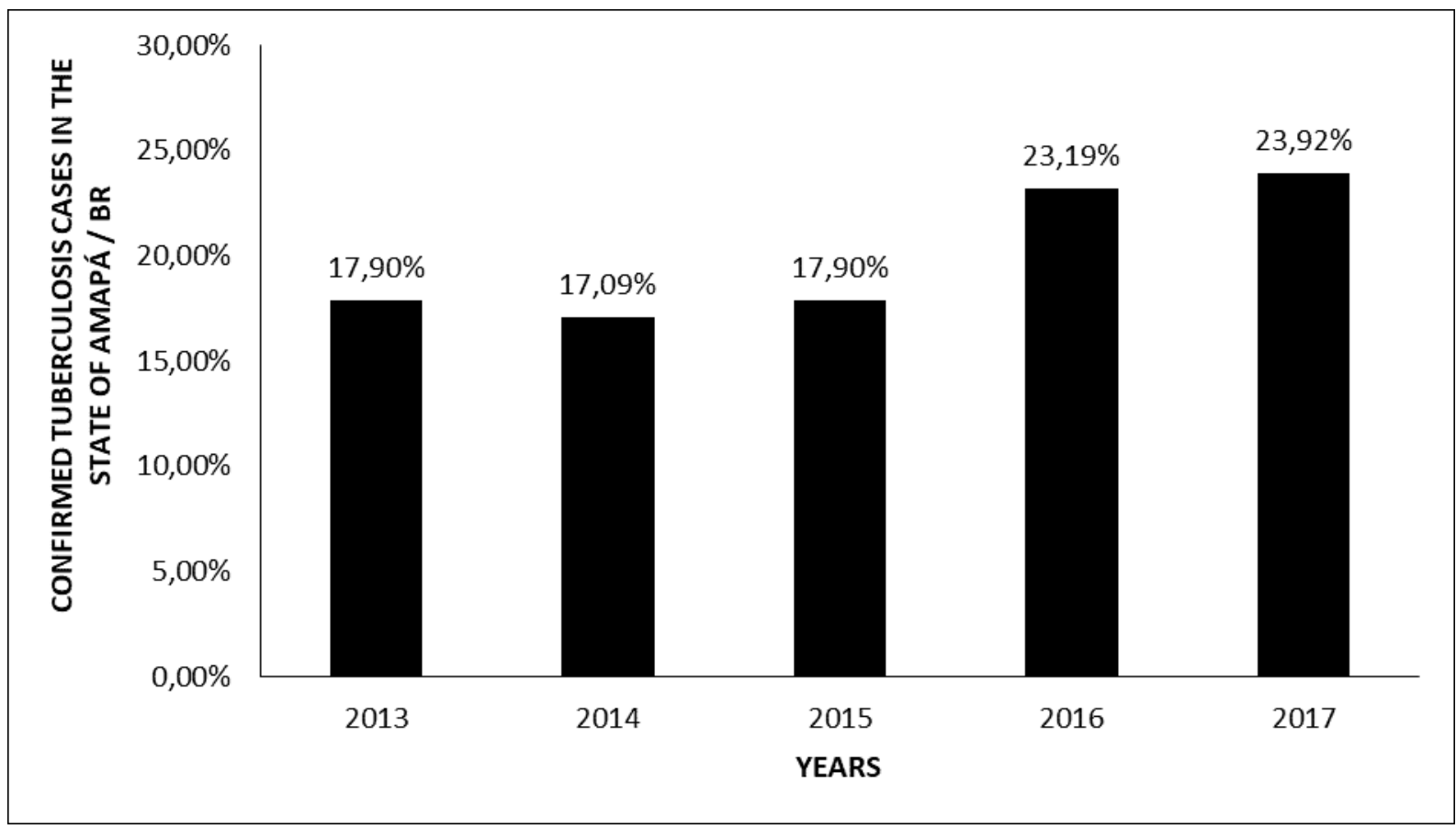

Figure 5 shows the percentage of confirmed cases of tuberculosis in the city of Macapá / AP between the years 2013 and 2017. From 2013 to 2014 the percentage of confirmed cases had a small decrease, and from 2015 to 2017 it grew.

RC: 49737

Available in: https://www.nucleodoconhecimento.com.br/health/tuberculosis-in-brazil 
Figure 5 Shows the percentage of confirmed tuberculosis cases in the city of Macapá / AP between the years 2013 and 2017.

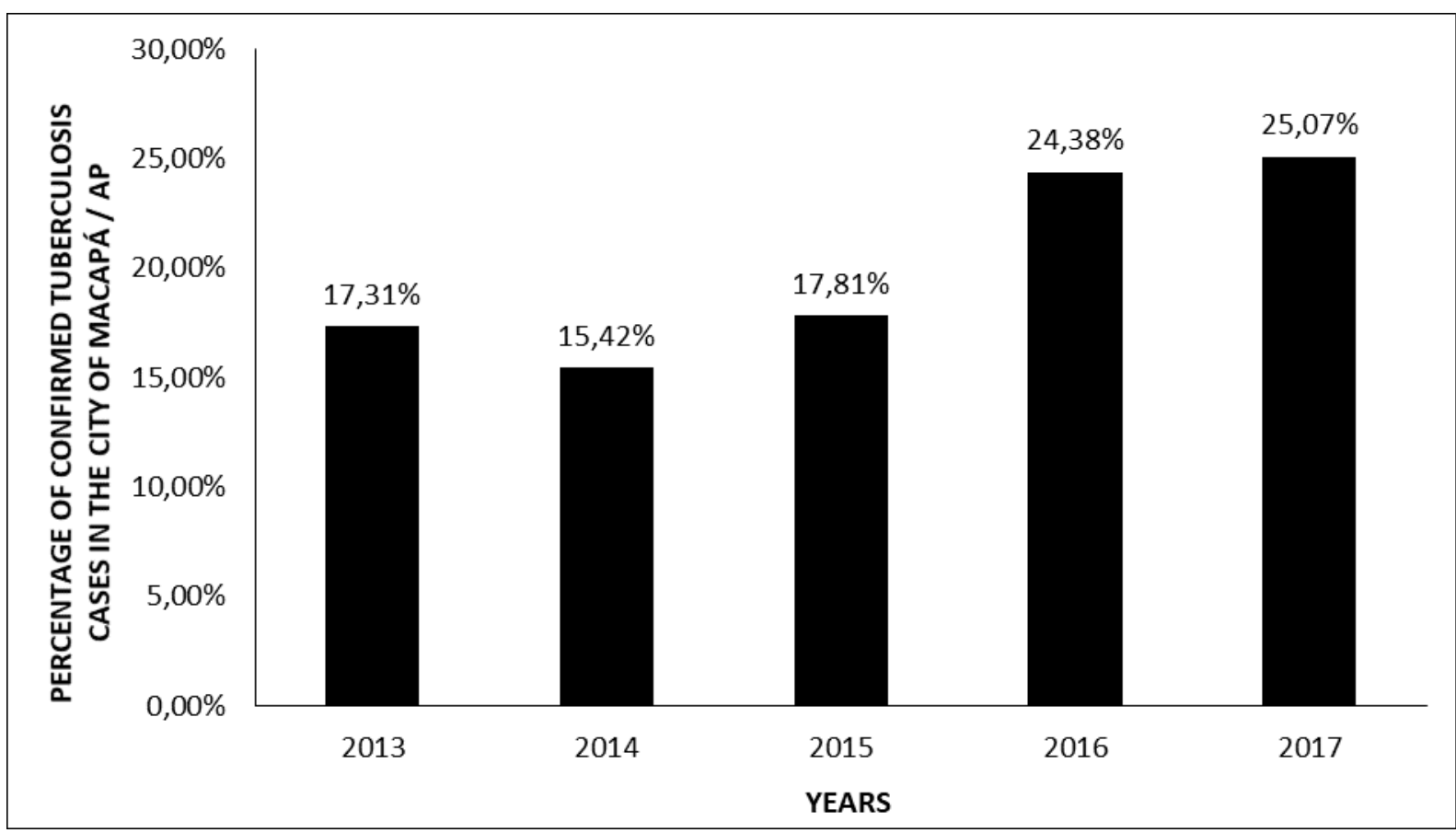

Figure 6 shows the percentage of confirmed cases of tuberculosis according to age group in the city of Macapá / AP between 2013 and 2017. Note that the highest percentages of confirmed cases are in the age group 20-39 and 40-59 and the smallest are those aged 60-79, 1-19, 80- + and $<1$ year.

RC: 49737

Available in: https://www.nucleodoconhecimento.com.br/health/tuberculosis-in-brazil 
Figure 6 Shows the percentage of confirmed tuberculosis cases according to age group in the city of Macapá / AP between 2013 and 2017.

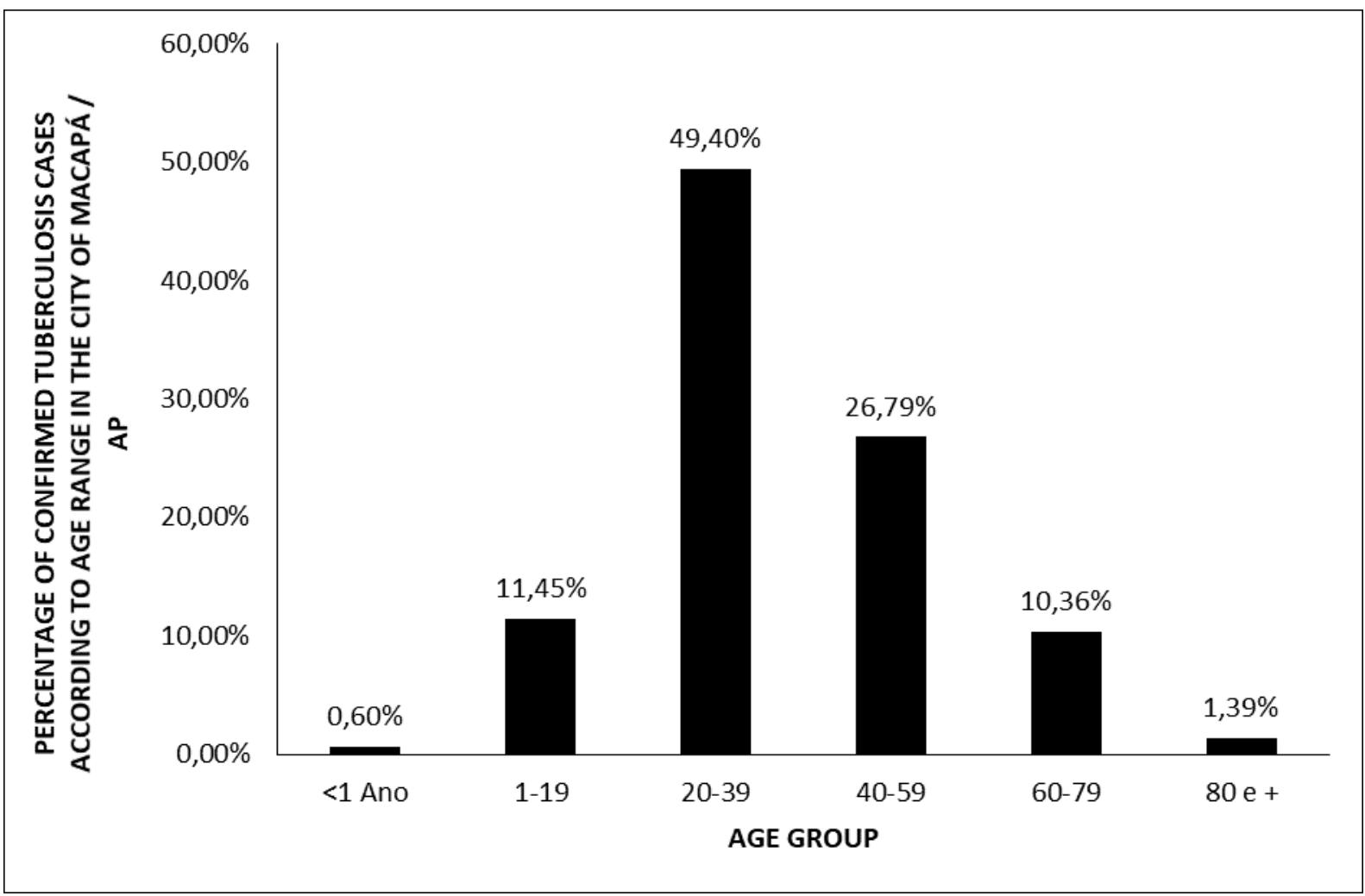

Figure 7 shows the percentage of confirmed cases of tuberculosis according to schooling in the city of Macapá / AP between 2013 and 2017. It is noted that the highest percentage of confirmed cases occurs in individuals with complete high school, followed by complete elementary school and University education. The lowest percentage of cases occurs in subjects with 4th grade of complete elementary school. The rate of ignored or blank cases is higher than all others.

RC: 49737

Available in: https://www.nucleodoconhecimento.com.br/health/tuberculosis-in-brazil 
Figure 7 Shows the percentage of confirmed tuberculosis cases according to schooling in the city of Macapá / AP between 2013 and 2017.

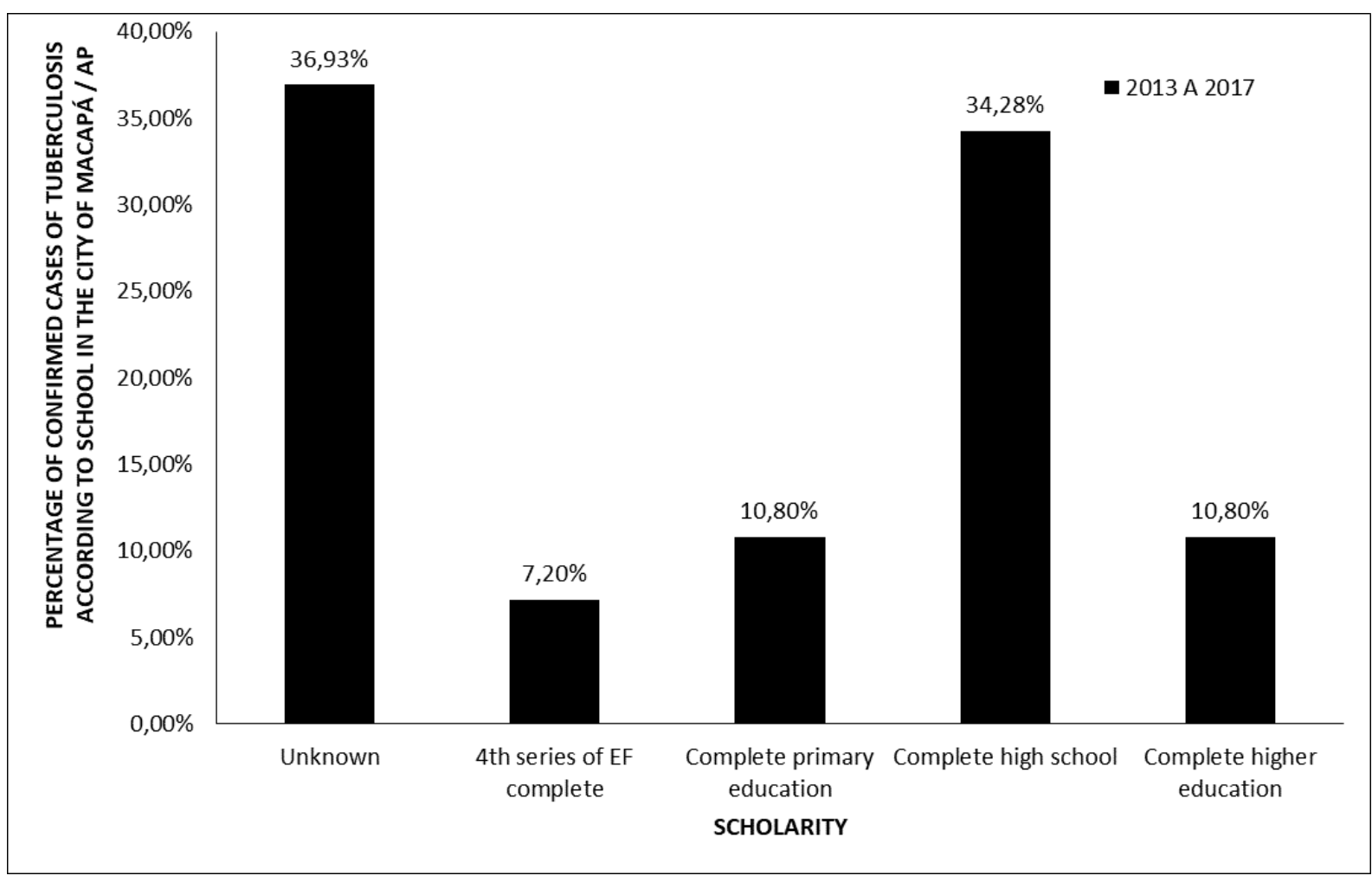

\section{DISCUSSION}

One of the main factors that may be correlated to the increase in cases of tuberculosis (TB) in Brazil, in 2016 and 2017 (Figure 1), is coinfection with the human immunodeficiency virus (HIV) (BRASIL, 2017a). This co-infection is responsible for weakening the individual's immune system, facilitating the entry of opportunistic organisms, as is the case of Koch's bacillus, which causes tuberculosis. Compared to 2015, in 2016 there was an increase of $4 \%$ in the number of new HIV infected (38,090 cases) in Brazil. Still in 2016, about $76 \%$ of new TB cases were tested for possible HIV co-infection and, among them, 12\% (6501 people) were co-infected, denoting a significant portion of the value (BRASIL, 2017b). In addition, in general, alcoholism, drug use, socio-spatial conditions (urban agglomerations),

RC: 49737

Available in: https://www.nucleodoconhecimento.com.br/health/tuberculosis-in-brazil 
socioeconomic conditions and the individual's nutritional status may also represent factors linked to the occurrence of TB (VALENTE et al., 2019).

The Southeast region (Figure 2) has the largest population by region and many of its municipalities have a high Human Development Index (HDI). However, it also has a high rate of people in situations of social vulnerability, characterized by several factors, with the scarce coverage of primary health care being one of the main ones. The wide economic inequality is reflected in access to health, since the poorest are unable to turn to private hospitals for treatment, depending largely on primary care services. (RANZANI et al., 2018).

The state of Amazonas (Figure 3) has a large indigenous population more susceptible to the aggravation of diseases caused by microorganisms, due to precarious and unfavorable health conditions (mainly in its portion of the international border that comprises a total of 9,058 kilometers from Acre to Amapá). Due to the great movement in the border space, interpersonal transmission of tuberculosis is easy (BELO et al., 2013). In Pará, due to the increase in the number of needy regions and with the dense and disordered growth of urbanized regions (scarcity of sanitation, water and electricity), there was also an increase in the incidence of tuberculosis cases, reinforcing the influence of economic and socio-spatial factors in the high number of cases of the disease (LIMA et al., 2017).

In Amapá (Figure 4), the body responsible for the specialized care service for infectious diseases, including tuberculosis, is the Tropical Diseases Reference Center (DRC), which also includes the Testing and Counseling Center (TCC) and Assistance Home Therapy (AHT). The increased coverage of the testing and diagnosis system in some municipalities in the state may have been responsible for revealing previously undetected cases, which were outside the available data(AMAPÁ, 2016).

The capital Macapá (Figure 5) is one of the five cities in which it is possible to test for tuberculosis in the state of Amapá (AMAPÁ, 2016). In 2016, it covered 151 of the 230

RC: 49737

Available in: https://www.nucleodoconhecimento.com.br/health/tuberculosis-in-brazil 
new cases of tuberculosis in the state, and of those cases, $16 \%$ represented HIV coinfections (BRASIL, 2017b). In 2017, along with Roraima, Macapá had one of the highest rates of detection of AIDS (Acquired Immunodeficiency Syndrome), being 29.8 per 100 thousand inhabitants. Thus, cases of co-infection therefore tend to increase, increasing the total number of cases of tuberculosis (BRASIL, 2018).

Analyzing the panorama of tuberculosis in Brazil, the age group most affected by women is 20-39 years. In men, the age group is 40-59 years. Men represent the majority of the incidence in the country. In 2012 its incidence was 50.2 per 100 thousand inhabitants, a value more than 2 times higher than that of women (BRASIL, 2017a). Thus, when analyzing the graphs in figure 6, we notice that Macapá corresponds to the national average age group for tuberculosis. In adulthood, in addition to facing larger crowds of people due to work, which increases transmission (LIMA et al., 2017), the BCG vaccine has no effect (CARVALHO et al., 2018). This can make adults more susceptible by increasing the number of cases in this age group (SILVA et al., 2020).

At the national level, the profile for tuberculosis infection is directly linked to men, especially those who are economically active and have a low level of education. They have little access to information about tuberculosis throughout their lives and a low understanding of the pathology and its organic consequences. Socio-spatial segregation and low income are also part of this profile. All of these factors, combined, end up causing the comprehensive abandonment of TB treatment. In view of this therapeutic interruption, the individual can favor the selection of bacteria, leading to drug resistance and, consequently, the possible worsening of the disease (RODRIGUES e MELLO, 2018).

\section{CONCLUSION}

Co-infections as well as alcoholism, drug use, urban agglomerations and the individual's nutritional status can also represent factors that increase tuberculosis cases. Social vulnerability and little primary health care also favor an increase in

$\mathrm{RC}: 49737$

Available in: https://www.nucleodoconhecimento.com.br/health/tuberculosis-in-brazil 
these numbers. Having a Tropical Diseases Reference Center (CRDT), which also includes the Testing and Counseling Center (CTA) and Therapeutic Home Assistance (ADT) helps in detecting cases, streamlining and controlling the treatment of patients. Men in the working age group are more affected due to their necessary social interaction for work.

\section{REFERENCES}

AMAPÁ. Plano Estadual de Saúde 2016-2019. Macapá AP: Governo do Estado do Amapá: 244 p. 2016.

BELO, E. N. et al. Tuberculose nos municípios amazonenses da fronteira BrasilColômbia-Venezuela: situação epidemiológica e fatores associados ao abandono Rev Panam Salud Publica, v. 24, n. 5, p. 321-329, 2013.

BRASIL. Boletim Epidemiológico. Brasilia DF: Ministério da Saúde. 40: 12 p. $2017 a$.

Boletim Epidemiológico HIV AIDS. Brasilia DF: Ministério da Saúde: 64 p. 2017b.

Boletim Epidemiológico 11. Brasilia DF: Ministério da Saúde. 49: 18 p. 2018.

. Manual de recomendações para o controle da tuberculose no Brasil. Brasilia DF: Ministério da Saúde: 366 p. 2019.

CARVALHO, A. C. C. et al. Aspectos epidemiológicos, manifestações clínicas e prevenção da tuberculose pediátrica sob a perspectiva da estratégia End TBv. J Bras Pneumol., v. 44, n. 2, p. 134-144, 2018.

KOZAKEVICH, G. V.; SILVA, R. M. D. Tuberculose: Revisão de Literatura. Arq. Catarin Med. , v. 44, n. 4, p. 34-47, 2015.

$\mathrm{RC}: 49737$

Available in: https://www.nucleodoconhecimento.com.br/health/tuberculosis-in-brazil 
LIMA, S. S. et al. Análise espacial da tuberculose em Belém, estado do Pará, Brasil. v. Rev Pan-Amaz Saude, n. 2, p. 57-65, 2017.

MACEDO, J. L. et al. Perfil epidemiológico da tuberculose em um Município do Maranhão. ReonFacema, v. 3, n. 4, p. 699-705, 2017.

RANZANI, O. T. et al. Quem são os pacientes com tuberculose diagnosticados no pronto-socorro? Uma análise dos desfechos do tratamento no estado de São Paulo, Brasil. J Bras Pneumol, v. 44, n. 2, p. 125-133, 2018.

RODRIGUES, M. W.; MELLO, A. G. N. C. Tuberculose e escolaridade: Uma revisão de literatura. Revista Internacional de Apoyo a la Inclusion, Logopedia, Sociedad y Multiculturalidad, v. 4, n. 2, p. 01-12, 2018.

SILVA, F. T. et al. Número de casos confirmados de tuberculose no Brasil entre 2007 e 2016. Revista Científica Multidisciplinar Núcleo do Conhecimento, v. 4, n. 8, p. 94-104, 2020.

SILVA, M. E. N. D. et al. Aspectos gerais da tuberculose: uma atualização sobre o agente etiológico e o tratamento. RBAC, v. 50, n. 3, p. 228-232, 2018.

VALENTE, B. C. et al. A tuberculose e seus fatores associados em um município da região metropolitana do Rio de Janeiro. , v. 22, e190027, . Rev Bras Epidemiol, v. 22, p. 1 - 12, 2019.

WHO. Global Tuberculosis Report. Executive Summary. 2019. Disponível em: < https://www.who.int/tb/publications/global_report/GraphicExecutiveSummary.pdf?ua= 1\&ua=1 >. Acesso em: 03 maio 2020.

7. http://datasus.saude.gov.br/

8. http://datasus.saude.gov.br/

Submitted: May, 2020.

RC: 49737

Available in: https://www.nucleodoconhecimento.com.br/health/tuberculosis-in-brazil 
Appproved: May, 2020.

RC: 49737

Available in: https://www.nucleodoconhecimento.com.br/health/tuberculosis-in-brazil 